IKONOMIKA: Jurnal Ekonomi dan Bisnis Islam

Volume 4, No. I (2019)

ISSN : 2527-3434 (PRINT) - ISSN: 2527-5I43 (ONLINE)

Page : I - I2

\title{
Optimization Of The Government's Role \\ In Supporting The Socialization Strategy Of Sharia Pawn Products
}

\author{
Ning Karnawijaya \\ IAIN Surakarta \\ ning k83@yahoo.com
}

\begin{abstract}
$A B S T R A C T$
Sharia pawn products (rahn) are one of the sharia financial services products that are growing over time. However, this development still requires attention in order to achieve financial inclusion and increase market share of sharia pawn products. One of the efforts to realize this goal is the socialization strategy. The success of socialization is not only the responsibility of the Islamic financial services institution, but also the role and support of other stakeholders, especially the government. The government through BI and OJK has a strategic role in helping these efforts. Optimizing the role of the government in supporting the dissemination of sharia mortgage products can be done with strategic steps namely targetting, integrating, understanding, and implementing.
\end{abstract}

Key words $\quad$ :Role of government, Socialization, Sharia pawning

\section{A. INTRODUCTION}

Islamic financial services business continues to experience development over time. Along with the development of studies on Islamic economics and the emergence of new policies related to Islamic financial services business, the support of various parties such as BI, DSN MUI, OJK, and other stakeholders with an interest in the development of Islamic economics also spurred the development of Islamic financial services business. Significant developments can be seen from the birth of various Islamic financial services products as an instrument in the application of Islamic economics which is expected to attract the public.

Based on the results of the OJK national survey on 2016 financial literacy and inclusion, showed the development of the pawnshop financial literacy sector from $14.85 \%$ in 2013 to $17.82 \%$ in 2016 . Likewise with the pawnshops financial inclusion of $5.04 \%$ in 2013 increased to $10.4 \%$ in 2016. As for Sharia pawnshop sector financial literacy index of $1.63 \%$ and financial inclusion of $0.71 \%$. Although not too large but based on the data, it shows that the pawnshop sector has increased in the last 5 years. This proves that there is still optimism to develop this pawn service business sector.

Received :November I0, 2018 - Revised: January 04, 2018 - Accepted :January 22, 2018 IAIN Surakarta

E-mail: ning_k83@yahoo.com 
One of the sharia financial services related to pawning is a sharia pawn products (rahn). Sharia pawn products developed after the issuance of DSN MUI Fatwa Number 25 of 2002 concerning rahn, DSN MUI Fatwa No. 26 of 2002 concerning rahn gold, and DSN MUI Fatwa No. 68 of 2008 concerning rahn tasjily. After the DSN issued a regulation on sharia pawning, the sharia pawning contract can be provided by Islamic financial services institutions, whether by Islamic banks, sharia pawnshops or other Islamic financial services institutions. Thus, sharia pawn products are no longer a monopoly of sharia pawnshops.

The development of Islamic pawning needs to be appreciated as a positive indicator in attracting public interest to access the product. But in its development, the application of the Islamic pawn product is not without problems. It is undeniable that sharia pawn products are still less desirable in the market. This is partly because many people do not know and understand sharia pawn products. Not only the introduction of the product but also the financial services institutions that provide the sharia pawn product. Most people just know that the sharia pawning product is only provided by sharia pawnshops, where access to the community is still limited. Therefore, it is needed socialization to the public about the existence, benefits and advantages of sharia pawning products so as to attract the interest of the community. Socialization is very important because the socialization is expected to increase market share of sharia pawn products.

Sharia product socialization to the community requires cooperation and participation from various parties. In addition to financial services institutions that issue sharia pawn products and DSN MUI as the party issuing fatwas, the government through BI as the role of monetary and OJK policies that play a role in coaching and supervision has a strategic role in supporting the socialization strategy to the public about the existence and benefits of sharia pawn products. Socialization in the effort to develop a product to the community becomes something important to be done widely, continuously and continuously. Therefore, it is necessary to study the efforts that can be carried out by the government in supporting effective sharia product socialization strategies so that it can provide an understanding to the public about the benefits and knowledge of sharia pawn products. Thus it is expected to help increase market share of sharia pawn products. 


\section{B. THEORITICAL}

\section{View of Role}

Role is a dynamic aspect in the position of something. If someone does his rights and obligations according to his position, then he runs a role (Suharto, 2002, Soekamto, I984: 237). Related to the role of the government, especially in socializing sharia pawn products, the government is expected to be able and able to carry out their rights and obligations according to their function and position.

Horoepoetri, Arimbi and Santosa (2003) propose the following role dimensions:

I. Role as a policy. These adherents argue that the role is an appropriate and good policy implement.

2. Role as a strategy. Adherents of this understanding postulate that the role is a strategy to get support from the community (public support).

3. Role as a communication tool. The role is utilized as an instrument or tool to get input in the form of information for decision making. This perception is based on a thought that the government is designed to serve the community, so that the views and preferences of the community are valuable inputs to realize responsive and responsible decisions;

4. Role as a dispute resolution tool, the role is utilized as a way to reduce or reduce conflict through efforts to reach consensus from existing opinions. The assumption that underlies this perception is that exchanging thoughts and views can increase understanding and tolerance and reduce feelings of distrust and confusion.

5. Role as therapy. According to this perception, the role is performed as a psychological effort of the community as well as feelings of helplessness, lack of confidence and a feeling that they are not an important component in society.

Some dimensions of the role can provide what direction and how to optimize the role of the government in this regard related to the socialization of sharia pawn products. Optimizing the role of the government is expected to be able to support efforts to increase market share of sharia pawn products.

\section{Strategy of Sozialization}

The strategy according to Thompshon (in Oliver, Sandra, 2007) is a way to achieve an end result regarding the goals and objectives of the organization. Meanwhile, according to Bennet (in Unong Uchjana Effendi, 2003) strategy is the direction that people choose to follow in achieving their mission. The strategy is essentially planning and management to achieve a goal. But to achieve this goal, the strategy does not function as a road map that shows direction only, but must show how the operational tactics. 
In the large Indonesian dictionary, socialization is defined as an effort to socialize something so that it becomes known, understood and lived by the community. According to David A. Goslin (in Ihrom, 2004) states that socialization is a learning process experienced by a person to acquire skills knowledge, values and norms so that he can participate as a member and community group. The socialization itself consists of deliberate socialization and unintentional socialization. Intentional socialization, which is a conscious socialization, such as education, teaching, preaching, giving instructions, advice and others. Whereas unintentional socialization is a daily behavior or attitude that is seen or imitated by other parties (Narwoko, J Dwi and Bagong Suyanto, 2006).

Based on the understanding of the socialization above, it can be stated that socialization is a process by carrying out various activities and efforts so that other people or the community can accept, have interests, and do according to the dissemination material presented. Sharia pawn product socialization is a process by carrying out various activities and efforts so that the community has awareness, interest, and encourages the community to utilize and access the sharia pawn product. While the socialization strategy is a plan, a way, a series of activities in disseminating what you want to convey to the community to achieve the end goal or outcome. The strategy of sharia pawning product socialization is a plan, method, and series of activities in disseminating sharia pawning products to the public to increase market share of sharia pawning products in particular and the welfare of society in general.

\section{Sharia Pawn}

The Civil Code Article II50 states "Pawn is a right obtained by a debtor on a movable item, which is surrendered to him by an indebted person or another person on his behalf, and who gives the debtor the power to take repayment from the item as take precedence over people to auction the item and the costs incurred to save it after the item is pawned, which costs must be made "(R. Subekti and R Tjirsudibio, 1976).

Sharia pawning (rahn) is holding one of the customer's property (rahin) as collateral (marhun) for the debt or loan (marhun bih) that he receives. Marhun has economic value. Thus, the party holding or receiving the pawning (murtahin) gets a guarantee to be able to take back all or part of the debt (Muhammad Syafi'I Antonio, 200I).

The Qur'anic Letter of Al Baqarah: 283 becomes the legal basis for the existence of rahn, which means: "If you are on a journey (and bermuamalah not in cash) while you do not get a writer, then there should be dependents held (by the 
debtor). However, if some of you trust some of the others, then those who believe are fulfilling their mandate (debt) and let those who trust them fulfill their mandate (debt) and let them fear Allah their Lord; and do not (witnesses) hide testimony. And whoever hides it, then he is truly a sinner of his heart; and Allah knows best what you do.

The legal foundation of the Sunnah of Rosululloh is based on the AlHadith. "Verily the Messenger of Allāh membeli had bought food with debt from a Jew, and the Prophet pawned an armor to him. (HR. Bukhari and Muslim) ". While Jumhur Ulama agreed on the status of liens. This is meant, based on the story of the Prophet Muhammad, who pawned his armor to get food from a Jew. The scholars also took an indication of the example of the Prophet Muhammad SAW, when he switched from the attitude of the Prophet Muhammad SAW who did not want to burden the friends who are usually reluctant to take over or the price given by the Prophet Muhammad to them (M. Ali Hasan, 2004).

The Fiqh scholars agreed to declare that ar-rahn may be carried out on the way and in a state of attendance at the place, provided that the collateral goods can be directly held / controlled ( $a$ l-qabdh) legally by the debtor directly, then there is at least some kind of guarantee that can guarantee that the goods are in marhun status (being debt collateral). For example, if the item is in the form of a piece of land, then what is controlled $(a l-q a b d h)$ is the land guarantee letter (Nasroen Haroen, 2007).

DSN-MUI Fatwa Number: 25 / DSN-MUI / III / 2002 Regarding ArRahn, it is stated that loans using goods as collateral in the form of sharia (Rahn) pledges are permitted, namely a form of surrender of the borrower's assets as collateral for loans received it.

\section{Sharia Pawn Practices}

The sharia pawning practiced by Islamic financial services institutions is to lend money to customers with collateral that is valuable and can be sold. The money lent is without interest. However, the customer (rahin) is obliged to submit the collateral (marhum) for the benefit of debt repayment when the customer cannot pay the debt at the agreed maturity date. Guaranteed items will be sold to cover debt with customer confirmation as a pledge. If the collateral has been sold in accordance with the market price, the recipient of the pawn only takes it in accordance with the debt value and the return is returned to the customer. Maintenance and maintenance costs, including administration fees paid by the customer as the plaintiff as agreed. 
A pawn is to borrow something either goods or money by giving a guarantee in the form of goods to the lender. If the borrower cannot pay the loan at maturity, the collateral item can be sold to repay the loan. Thus in the pawn there are two elements, namely borrowing something and guaranteeing goods. In accordance with the times, pawning is now combined with other contracts. Initially the scholars did not allow a pledge contract that was mandated to be combined with other contracts, such as mudharabah, musyarakah and wadi'ah contracts.

The pledge recipient (murtahin) can use collateral goods so that there is no need to provide collateral maintenance costs (marhun). If the recipient of the pawn does not make use of the collateral item and is obliged to maintain it until the agreed time limit, then the pawner (rahin) must issue costs (mu'nah) related to the maintenance of the collateral item. The cost of maintaining collateral goods is adjusted to the value of the goods and equipment of their needs. As explained by the Messenger of Allah: "The mortgages (vehicles) that are pawned may be ridden by bearing the costs and the pawned animals can milk their milk by covering the costs. People who use vehicles and milk must bear the cost of care and maintenance."

\section{Benefits and Advantages of Sharia Pawn Products}

Islamic pawn products have many benefits and uses in their application. Not only for consumptive but also productive financing. Islamic pawning application combined with other contracts, such as mudharabah, musyarakah and wadiah contracts, allows sharia mortgage loans for productive financing. Whether it is productive based on customer needs for loans with sharia pawning, or financial institutions that provide sharia pawning services that wish to utilize pawning goods for productive activities.

Islamic pawn products are one of the products aimed at meeting the financial needs of the community quickly and easily. Among the advantages possessed by the Islamic pawn product are the term of the Islamic pawning. Islamic pawning is an alternative solution to meet short-term or less than one-year financial needs. For customers who have a loan repayment prediction of less than one year, with a low rate of return, the sharia mortgage product can be one solution. No need to wait yearly to repay the loan. Likewise flexibility in returns.

Technological developments encourage Islamic financial institutions to develop online features of financial services products. Islamic pawn products or rahn cannot be separated from this phenomenon. These developments make it easier for the public to access this rahn product. Repayment procedures that can be done at any time with a procedure that is quite easy and fast especially with an 
online system like today, making this product quite promising for its development. These developments are expected to be able to help attract consumers and increase financial inclusion of sharia pawn products.

\section{METHODOLOGI}

One of the successes of the financial industry in developing financial services products is the achievement of financial inclusion, namely the availability of access for the community to utilize financial products and / or services in financial service institutions in accordance with the needs and abilities of the community in order to realize prosperity (RPOJK, 20I6).

The purpose of financial inclusion is:

I. Increased public access to formal financial products and services.

2. Increasing the supply of formal financial institutions products and / or financial services

3. Increased utilization of products and / or financial services that are in accordance with the needs and abilities of the community.

One of the efforts to achieve the objectives of financial inclusion is the strategy of socialization. Socialization continues to be carried out with the aim, so that sharia services and services products are diverse, competitive and can be recognized and utilized to meet the needs of the wider community, and to contribute significantly and optimally to sustainable national economic growth and development (Edi Setiadi, 20I7).

Islamic financial institutions as providers of sharia pawn products certainly have various steps and activities as a strategy in socializing sharia pawn products. The efforts that have been carried out by the sharia financial institutions will be stronger if supported by the government by both BI and OJK and other related government institutions. The government is expected to optimize its role in contributing to supporting the efforts and strategies of socialization carried out by the Islamic financial institutions. Thus the government participates in helping the realization of the objectives of sharia pawn product socialization.

\section{RESULS AND DISCUSSION}

Optimizing the role of the government needs to be proactive from various parties concerned with increasing market share of pawn products. This cannot be done only by expecting concern from government agencies without attracting the interest of government agencies to support the development of this product. There 
are several important steps to optimize the role of the government in supporting the sharia product socialization strategy, namely:

I. Targeting.

Targeting is the determination of the target of socialization, which is to segment the groups of people who are the target of socialization. Determination of the target of this socialization will greatly influence the determination of which government institution or government party to be invited to cooperate in supporting the socialization of the pawn product.

As an example the target of socialization is small and medium entrepreneurs or UMKM with the assumption that the sharia pawn product can be a productive financing solution to finance short-term orders or projects, where after the project or the order is finished the loan can be returned immediately. So the government can be invited to collaborate, such as the Ministry of Cooperatives and UKM, the Regional Government, or other governments that are related and have an interest in the development of UMKM.

2. Integrating

Proactive attitude to attract the interest of government participation is needed, especially by the OJK as a supervisor and coach of Islamic financial services institutions or Islamic financial services institutions themselves as subjects who issue sharia pawn services. After determining the relevant government, it is necessary to have an integration between the concerned institutions. Thus, government institutions that will integrate and support are adjusted to the targets of socialization that have been determined.

Forms of integration can be done starting from equating perceptions, objectives and vision and mission of socializing sharia pawning products to forms of support that can be done by the government. The cooperation and integration are expected to benefit not only the achievement of the goals of the parties that are integrated in the short term but also to improve the welfare of the community.

3. Understanding

Socialization will not be effective without the knowledge and understanding of the products to be socialized. The parties that integrate in the product socialization of the Islamic pawn must have sufficient knowledge and understanding of the sharia pawning products. Sharia pawn product socialization can succeed and can achieve the expected goals with adequate knowledge and understanding of sharia pawn products. Knowledge and understanding that must be possessed are: 
a. Understanding the concept, is an understanding of the product that is socialized, namely sharia pawn products, about what is a sharia pawning, the difference with conventional pledges as well as the terms and conditions.

b. Understand the application, is an understanding of the operation or practice of Islamic pawning. Including the development of sharia pawning products, or types of sharia pawn products.

c. Understanding the benefits and advantages, this is very important in the success of the socialization strategy. The conveying of information about the benefits and advantages of this product to the community is a determining factor in the interest of the community to access the product.

d. Understand the access of service institutions that provide these products. After attracting public interest in sharia pawn products, the public needs information on the service institutions that provide these products. Therefore, it is necessary to know about Islamic banks, sharia pawnshops or other Islamic finance institutions in the vicinity of the people who are the target of the socialization, which provides the sharia pawn product.

4. Implementation

Implementation is a concrete step in optimizing the role of the government in supporting the strategy of socializing sharia pawn products. The implementation of the role of the government in supporting the sharia product socialization strategy can be done with the following:

a. Participate in strategic socialization activities that are held specifically by OJK or financial service institutions providing sharia pawn products. OJK itself has a socialization strategy in an effort to increase public understanding of Islamic financial products and services. Like the "Aku Cinta Keuangan Syariah" (ACKS) campaign which was inaugurated by President Joko Widodo June I4 2015 as one of the efforts to support the growth of the Islamic financial services industry. In addition, the Islamic Fair Financial activities (Keuangan Syariah Fair) are in the form of sharia financial industry exhibition/expo followed by Islamic Banks, Sharia Capital markets, and Sharia IKNB. KSF is one of OJK's strategies to bring people closer to the Islamic financial industry as a means to obtain information about the advantages of Islamic financial products and services. Likewise with Islamic financial institutions that provide sharia pawn products such as Islamic banking and sharia pawnshops. But what needs to be noted is that government involvement is not necessarily easily obtained. Need to approach and communicate with the government or 
government agencies that are expected to support and participate. Therefore, the need for integration at the beginning before implementation.

b. Actively carry out the public campaign as a public dissemination of sharia pawning products in each of the activities of the government institution concerned. Especially activities that have the prospect of attracting the audience / community to access and utilize sharia pawn products.

c. Use of Media Socialization.

Simple Financial Products and / or Services are products and / or financial services with features and requirements that are simple, easy and affordable for various groups of consumers and / or the community. The use of media is crucial to be optimized. The results of the OJK's 2016 financial literacy and inclusion survey show that the sources of information that influence people's decisions in accessing the largest financial services are through the media, especially electronic media. Whether it's through TV ads, or other online media. Like the popularization of the pawnshop "solving problems without problems" is one example of the effectiveness of the media as a means of socialization. Given the importance of the role of the media, there is a need for new innovations, more creativity, especially in changing the paradigm in the community about pawning products that are still inherent in the community, namely that pawning is financing for distressed people or the weak who lack. In addition, creativity through the media is able to encourage the birth of a new slogan about sharia pawning products that are expected to be able to emerge and upload the benefits of sharia pawn products. For example, related to its membership as an alternative to short-term financing solutions. Thus, the public is increasingly interested in sharia pawn products and is able to increase market share of sharia pawn products.

The implementation steps need an active role from the parties involved in planning and implementing them. Effective implementation and strategy steps that are able to support the achievement of the objectives of sharia pawn product socialization can be done by synergizing various programs and activities of related parties.

\section{E. CONCLUSION}

The role of the government is needed in supporting the strategy of socializing sharia pawn products. Several steps can be taken to optimize the role of the government in an effort to support the strategy of socializing sharia pawn products, namely, targeting, integrating, understanding and implementing. 
Targetting is the determination of the target of socialization. Targeting is also carried out to determine which government is expected to play its role. Integrating is carried out by integration and cooperation between governments related to parties concerned with sharia pawn product socialization, such as OJK and Islamic financial services institutions that provide sharia financial services products. Undestanding is an adequate knowledge and understanding of sharia pawn products. Implementing is a concrete step in optimizing the role of the government in an effort to support the strategy of socializing sharia pawn products. Some of these strategic steps are expected to be able to optimize the role of the government in an effort to support the strategy of socializing sharia pawn products.

\section{BIBLIOGRAPHY}

Arimbi, Achmad Santosa. (2003). Peran Serta Masyarakat dalam pengelolaan Lingkungan, Jakarta:Walhi

Edgina, L., Jazil, T., \& Nursyamsiah, T. (2017). STRENGTHENING THE ROLE OF

ISLAMIC PAWNSHOP IN ISLAMIC FINANCING FOR MSMES: ANP

APPROACH. Tazkia Islamic Finance and Business Review, IO I).

Edi Setiadi, Siaran Pers Kinerja Keuangan Syariah Indonesia Terus Meningkat, 2017.

www.ojk.go.id

Ihrom. (2004). Bunga Rampai Sosiologi Keluarga. Jakarta: Yayasan Obor Indonesia

M. Ali Hasan. (2004). Berbagai Macam Transaksi dalam Islam (Fiqh Muamalat). Jakarta: PT. Raja Grafindo Persada

Muhammad Syafi'I Antonio. (200I). Bank Syariah dari Teori ke Praktik. Jakarta: Gema Insani Press

Narwoko, J Dwi dan Bagong Suyanto. (2006). Sosiologi: Teks Pengantar dan Terapan. Jakarta: Kencana

Nasroen Haroen. (2007). Fiqh Muamalah, Jakarta: Gaya Media Pratama

Oliver, Sandra. (2007). Strategic Public Relations. Jakarta: Erlangga

Purnamasari, F. (2017). Pertumbuhan Ekonomi: Investasi Pemerintah Dan Manajemen Investasi Dalam Perspektif Islam (Studi Di Kabupaten/Kota Provinsi Lampung). Jutnal Manajemen Indonesia, I7( I), I3-26.

Purnamasari, Femei, and Arif Darmawan. "Islamic Banking and Empowerment of Small Medium Enterprise." Etikonomi 16, no. 2 (2017): 22I-230.

R. Subekti dan R Tjirsudibio. (1976). Kitab Undang-Undang Hukum Perdata,. Jakarta: Pradnya Paramita

RPOJK. (2016). Peningkatan Literasi dan Inklusi Keuangan di Sektor Jasa Keuangan untuk Konsumen dan/atau masyarakat,. Pasal. II. www.ojk.go.id

Suryanto, T., Purnamasari, F., \& Kurniawan, M. (2018). Tax Revenue and Disparity: How to Improvement Income Inequality in Islamic Perspective. Asian Journal of Social Sciences and Management Studies, 5(2), 65-7I.

https://ejournal.radenintan.ac.id/index.php/ikonomika

E-mail:ikonomika_submission@radenintan.ac.id 
Optimization Of The Government's Role

In Supporting The Socialization Strategy Of Sharia Pawn Products

Ning Karnawijaya

Unong Uchjana Effendi. (2003). Ilmu, Teori dan Filsafat Komunikasi. Bandung: PT. Citra Aditya Bhakti 